\title{
GIDA KATKI MADDELERİNIN MİKROBİYOTA ÜZERİNE ETKİSİ
}

\author{
Hatice Merve Bayram, S. Arda Öztürkcan* \\ İstanbul Gelişim Üniversitesi, Sağlık Bilimleri Yüksekokulu, Beslenme ve Diyetetik Bölümü, İstanbul, Türkiye
}

Geliş / Received: 17.05.2020; Kabul / Accepted: 17.09.2020; Online bask1 / Published online: 30.09.2020

Bayram, H.M., Öztürkcan, S.A. (2020). Gıda katkı maddelerinin mikrobiyota üzerine etkisi. GID A (2020) 45(5) 1030-1046 doi: 10.15237/gida.GD20070

Bayram, H.M., Öztürkecan, S.A. (2020). Effects of food additives on microbiota. GIDA (2020) 45(5) 1030-1046 doi: $10.15237 /$ gida.GD20070

\section{ÖZ}

Mikrobiyota, mikroorganizmaların oluşturduğu topluluk olarak ifade edilmektedir ve bağırsak mikrobiyotası doğum ile birlikte değişmeye ve gelişmeye başlamaktadır. Beslenme, bakteriler için gerekli besinleri sağlayarak, mikro çev relerini değiştirerek ve kompozisyonlanı ile fonksiyonlarını modüle ederek mikrobiyota üzerine etkiler gösterebilmektedir. 20. yüzylın başlarından beri insanların diyetlerinde önemli değişiklikler görülmeye başlanmış olup özellikle işlenmiş gidalara yönelmeleri sonucu tüm bu vb. gidalara eklenen katkı maddelerinin tüketimleri artş göstermiştir. Karbonhidratlar, yağlar, proteinler ve fitokimyasallar gibi bazı diyet bileşenlerinin mikrobiyota üzerine etkisi değerlendirilmiştir fakat gida katkı maddelerinin mikrobiyota üzerine etkisi belirsizliğini korumaktadır. Günümüzde birçok gıda katkı maddesi için belirlenmiş üst limitler olsa da sağlığı olumsuz yönde etkileyebileceğini düşündüren çalışmalar mevcuttur. Bu nedenle mikrobiyota üzerine etkisini kapsamlı bir şekilde değerlendirerek toplumu bilinçlendirmek önem arz etmektedir. Bu derlemenin amacı gıda katkı maddelerinin bağırsak mikrobiyotası üzerine etkilerini inceleyen literatürde bulunan çalışmaları 3 grup halinde (tatlandırıcılar, emülsifiyerler ve diğer katkı maddeleri olarak) bir araya toplayıp güncel yaklaşımlar ile kapsamlı bir şekilde değerlendirmektir.

Anahtar kelimeler: Gıda katkı maddeleri, mikrobiyota, yapay tatlandırıcılar, emülsifiyerler

\section{EFFECTS OF FOOD ADDITIVES ON MICROBIOTA}

\begin{abstract}
Microbiota is expressed as the community of microorganisms and intestinal microbiota begins to change and develop with birth. Nutrition can affect the microbiota by providing the necessary nutrients for bacteria, changing the microenvironment and modulating the composition and functions of bacteria. Since the early 20th century, important changes have been seen in the diets, especially consumption of processed foods began popular hence consumptions of food additives, added to almost all these foods, have increased. The effects of some dietary components such as carbohydrates, fats, proteins and phytochemicals on microbiota have been evaluated but the effect of food additives on microbiota is still uncertain. Today, although there are upper limits for many food additives, studies suggesting that they may affect health negatively. Therefore, it is important to raise awareness of the society by comprehensively evaluating their effect on microbiota. The aim of this review is to collect the studies, determining the effects of food additives on gut microbiota in 3 groups (as sweeteners, emulsifiers and other additives) and to evaluate them comprehensively with current approaches.
\end{abstract}

Keywords: Food additives, microbiota, sweeteners, emulsifiers

* Yazışmalardan sorumlu yazar / Corresponding author

$\square$ : sozturkcan@gelisim.edu.tr, $\quad$ : (+90) 21242270 00/400

且 $(+90) 2124227401$

Hatice Merve Bayram; ORCID no: 0000-0002-7073-2907

S. Arda Öztürkcan; ORCID no: 0000-0001-7982-6988 


\section{GİRIŞ}

İnsanların gastrointestinal sistemlerinde vücutlarındaki somatik hücre sayısından yaklaşık 10 kat daha fazla mikroorganizma (yaklaşık 100 trilyon) bulunmaktadır (Cani ve Everard, 2016). Yaklaşık 1000 farklı tür içeren bağırsak mikrobiyotasında temel olarak en çok bulunanlar; Firmicutes, Bacteroidetes, Proteobacteria, Fusobacteria, Verrucomicrobia, Cyanobacteria ve Actinobacteria türleridir (Viennois ve Chassaing, 2018). Büyük ve karmaşı mikroorganizma popülasyonuna sahip bağırsak mikrobiyotası insanlarda sağlık ve hastalı̆ga katkıda bulunur ve bazen "unutulmuş organ" olarak adlandirilır (Clemente vd., 2012). Ayrıca insan bağırsak mikrobiyotası, insan genomunda bulunan genlerin 150 katından fazla gen bulundurmasının (Wang vd., 2017) yanı sıra fazla sayıda biyoaktif bileşen içerdiği için; bağırsak epitelinin bütünlügünün korunmasına, hücrehücre bağlantılarının korunmasına, yaralanma sonrası epitel onarımının teşvik edilmesine ve enterositlerin devir hızının düzenlenmesine de katk1da bulunur (Saad vd., 2012).

Mikrobiyotanın doğum sirasında (vajinal ya da fekal mikroflora yoluyla) değişmeye başlamasının yanı sıra, bileşimi ve işlevleri, yaşa, cinsiyete, 1rka, beslenme alışkanlıklarına, ilaç kullanımına ve çevresel faktörlere göre farkl1l1k göstermektedir (Sekirov vd., 2010; Wang vd., 2017). Bu faktörler arasinda yer alan beslenme, direkt veya indirekt olarak mikrobiyotayı etkiler ve bakteriler için gerekli besinleri sağlayarak, bakterilerin mikro çevresini değiştirerek ve bakterilerin kompozisyonu ile fonksiyonlanını modüle ederek bu etkilerini gösterebilmektedir (Biesiekierski vd., 2019; Le Roy vd., 2019; Schoeler ve Caesar, 2019; Zmora vd., 2019).

Diyet bileşenleri mikrobiyota bariyerinin koruyucu fonksiyonlarını ve konakçı-mikrobiyom dengesini bozabilir ve disbiyozise neden olarak inflamatuar süreçlere katkıda bulunabilir (Zmora vd., 2019). 20. yüzyllın başlarından beri insanların diyetlerinde önemli değişiklikler görülmeye başlanmış ve özellikle işlenmiş gıdalara yönelmeleri sonucu hemen hemen tüm işlenmiş gıdalara eklenen gida katkı maddeleri tüketimleri artış göstermiştir (Chassaing vd., 2015).
Karbonhidratlar, yağlar, proteinler ve fitokimyasallar gibi bazı diyet bileşenlerinin mikrobiyota üzerine etkisi değerlendirilmiştir fakat g1da katk1 maddelerinin etkisine dair bir netlik bulunmamaktadır. Artan işlenmiş gida tüketimi sonucu artan g1da katk1 maddeleri tüketiminin de mikrobiyotayı etkileyebileceği düşünülmektedir fakat bu konuda yapilan insan çalışmaları oldukça sınırlıdır (Roca-Saavedra vd., 2018). Bu derlemenin amac1 gida katk1 maddelerinin bağırsak mikrobiyotası üzerine etkilerini inceleyen literatürde bulunan çalışmaları 3 grup halinde (tatlandirıcilar, emülsifiyerler ve diğer katkı maddeleri olarak) bir araya toplayıp güncel yaklaşımlar ile kapsamlı bir şekilde değerlendirmektir.

\section{TATLANDIRICI OLARAK KULLANILAN GIDA KATKI MADDELERINIIN MİKROBİYOTA ÜZERİNE ETKİSİ}

Tatlandırıcılar, aşırı miktarda enerji alımından kaçınarak yiyecek ve içeceklerin lezzetini artırmak için kullanılan önemli şeker ikameleridir. Bazı çalışmalar, tatlandırıcıların vücut ağıllığı kaybında olumlu rol göstererek potansiyel bir vücut ağırlığ1 yönetimi arac1 olarak kullanılabileceğini göstermiştir (Bellisle vd., 2007; Husøy vd., 2008). Bununla birlikte bazı çalışmalar, tatlandırıcıların insan vücudunda aktif bir metabolik role sahip olduğunu ve glukoz intoleransını indükleyerek obezite ve metabolik sendroma neden olarak insan metabolizmasını bozabileceğini göstermiştir (Dhingra vd., 2007; Suez vd., 2014). Bağırsak mikrobiyotası üzerine etkisi en çok çalışılan grubu tatlandırıcılar oluşturmaktadır.

\section{Sakkarin}

İlk keşfedilen yapay tatlandırıcı olan sakkarin 1878 yllinda bulunmuştur ve 1981 yllinda Amerikan Gıda ve İlaç Dairesi (FDA) tarafindan onaylanmıştır (Özdemir vd., 2014). Sükrozdan 300-500 kat daha tatlı olup, özellikle diyabetik hastalar için en önemli ve yaygin kullanılan tatlandirıcidır (Özdemir vd., 2014; Amin vd., 2016). Günlük kabul edilebilir değeri (ADI) 5 $\mathrm{mg} / \mathrm{kg}$ doz şeklindedir (Cao vd., 2020). Sakkarin ne kadar güvenli olarak kabul edilse de olumsuz etkisi gösterilen çalışmalar mevcuttur. Örneğin bazı çalışmalar yüksek miktarlarda tüketiminin 
inflamatuar yanıtı artırabileceğini düşündürmektedir (Gong vd., 2016; Zhao vd., 2018; Kim vd., 2020). Başka bir çalışma, sakkarin tüketimi ile obeziteye yol açan glukoz intoleransı ve diyabet gibi metabolik sendromlar arasında bir korelasyon olduğunu göstermiştir (Foletto vd., 2016). Ayrica, mesane kanseri ve diğer kanser vakaları ile ilişskili olduğu da gösterildiğinden, tüketiciler risklerinin ve yararlarının farkında olmalıdır (Amin vd., 2016). Kullanım yaygınlığ1 en yüksek olan sakkarin, mikrobiyota üzerine etkisi en çok çalışılan grubu oluşturmaktadır.

In vitro bir çalışmada, \%2,5 sodyum sakkarin takviyesinin 20 saat sonunda Lactobacillus ve Escherichia coli (E. coli) türlerini azaltttğ1 bildirilmiştir (Naim vd., 1985). Farelere 10 gün boyunca $\% 7,5$ sodyum sakkarin takviyesi verildiğinde aerobik bakterilerde artış olduğunu gözlenmiştir (Anderson ve Kirkland, 1980). Başka bir çalışmada $\% 5$ ya da $\% 7,5$ sakkarin takviyesinin farelerde propiyonat, bütirat ve valerat seviyelerini azalttığ1 rapor edilmiştir (Anderson, 1985). Farelere 20 hafta süresince $50 \mathrm{~g}$ sakkarin takviyesi, 20. haftada toplam bakteri sayısın hem takviye verilmeyen hem de takviye verilen grupta artırmıs, amonyak konsantrasyonu ise sakkarin verilen grupta \%30-50 oranında artmıştır. Bu durumun bakteriyel enzim aktivitelerini azalttı̆ 1 gözlenmiştir (Mallett, vd., 1985). Yine farelere 40 gün $\% 7,5$ sakkarin takviyesi sonucu triptofanın metabolitleri olan indikan ve p-kresolün idrarla günlük atım miktarında 3-4 kat artış gösterdiği rapor edilmiştir. Çalışmada da belirtildiği üzere protein metabolizması bağırsak florasını değiştirmiştir (Lawrie vd., 1985). Domuzlar üzerinde yapılan bir çalışmada, domuzlara 2 hafta $\% 0,015$ sakkarin ve neohesperidin dihidrokalkon takviyesinin hem fekal Lactobacillus miktarında, hem de bağırsak lümeninde laktik asit konsantrasyonlarında artış gösterdiği saptanmıştur (Daly vd., 2014). Domuzlarda yapılan bir diğer çalışmada ise aynı süre ve dozda sakkarin ve neohesperidin dihidrokalkon takviyesi, benzer olarak Lactobacillus popülasyonunda oldukça yüksek bir artışa yol açmıştır (Daly vd., 2016). Farelere 11 hafta boyunca suda çözünmüş 0,1 $\mathrm{mg} / \mathrm{ml}$ sakkarin, sükraloz veya aspartam takviyesi verilen başka bir çalışmada, sakkarin alan grupta
Bacteroidetes ve bazı Clostridium türleri ile glikan bozunma ürünlerinde artış gözlemişlerdir. Yüksek seviyelerde bulunan glikan bozunma ürünlerinin, konakçı için enerji kaynağ1 veya glukoneogenez, liponeogenez ve kolesterol sentezi için sinyal molekülleri veya substratları olarak işlev görebileceği saptanmıştır (Suez vd., 2015). Yine farelere 6 ay suda çözünmüş $0,3 \mathrm{mg} / \mathrm{ml}$ sakkarin takviyesinin, indüklenebilir nitrik oksit sentaz (iNOS) ve tümör nekroz faktör- $\alpha$ (TNF- $\alpha$ ) aktivitelerini ve lipopolisakkaritler (LPS) ile bakteriyel toksinler gibi patojene bağlı moleküllerde artış sağlayan bakteri türlerinin sayılarını arttığı gösterilmiştir (Bian vd., 2017c). Farklı olarak, farelere 17 hafta \%0,3 sodyum sakkarin ve sodyum siklamat içeren yoğurt takviyesi mikrobiyotayı önemli ölçüde etkilememiştir (Falcon vd., 2020). İnsanlar üzerinde yapilan bir çalışmada ise 1 hafta sakkarin tüketimi sonrası bazı bireylerde glukoz intolerans1 görülmüş olup; bu kişilerin fekal mikrobiyotası mikropsuz farelere nakledildiğinde, Weissella ve Bacteroides fragilis sayılarında artı̧, göreceli olarak Candidatus Athromitus sayllarında ise azalma olmuştur. Ek olarak, fekal transplantasyonu yapılan bireylerde transplantasyon sonrası önemli glukoz intoleransı gözlenmiştir (Suez vd., 2014).

\section{Aspartam}

Aspartam 1965 yllında keşfedilmiş olup, 1981 yılında FDA tarafindan onay almıştır (Özdemir vd., 2014). Sükrozdan 180-200 kat daha tatlı olan aspartam, fenilalaninin karboksil ucunun metile edildiği fenilalanin ve aspartik asitten oluşan bir dipeptittir (Özbek ve Yentür, 1993; Ruiz-Ojeda vd., 2019). ADI değeri 40 mg/kg dozdur (Cao vd., 2020). Yapılan çalışmalar yüksek doz tüketiminin organların fonksiyonunu bozarak oksidatif strese neden olabileceğini ve hücre zarı bütünlüğüne zarar verebileceğini hatta kansere kadar götürebileceğini ortaya koymuştur (Ardalan vd., 2017; Choudhary ve Pretorius, 2017; Ali vd., 2019). Özellikle, aspartam diyabet, baş ağrısı, nöbetler, depresyon, artrit vb. tıbbi durumların alevlenmesi ile bağlantılıdır (John, 2016). Diyabetli bireylerde tüketimi önerilmemektedir çünkü diyabette yapay tatlandırıciların kullanımının diyabetin komplikasyonlarında kötüleşme ve obezite ile ilişkili sorunlara neden 
olabilecekleri gösterilmiştir (Imamura vd., 2015; Temizkan vd., 2015; Santos vd., 2018).

Aspartamın mikrobiyota üzerine etkisini değerlendiren çalışmalar sınırlıdır. Farelere 8 hafta boyunca $5-7 \mathrm{mg} / \mathrm{kg}$ günlük doz aspartam takviyesi, Clostridium leptum ve Enterobacteriaceae sayılarında artışa yol açmış ve aynı zamanda aspartam alımı, kısa zincirli yağ asidi olan propiyonat ve glukoneogenezin dolaşım seviyesini arttırmış ki bunun da hiperglisemi ve insülin toleransına yol açabileceği gösterilmiştir (Palmnäs vd., 2014). Başka bir çalışmada besin tüketim sıklığ1 formu kullanılarak insanların tatlandırıc1 tüketimini saptamışlar ve tatlandırıcı tüketimi olan kişilerde Enterobacteriaceae, Deltaproteobacteria ve Actinobacteria popülasyonlarında artış saptanmıştır (Suez vd., 2014). Ayrica, insanlar üzerinde yapilan bir diğer çalışmada, insanlara 4 gün boyunca 5,3 $\mathrm{mg}$ ile $112 \mathrm{mg}$ günlük doz aspartam ve $1,7 \mathrm{mg}$ ile 33,2 mg günlük doz asesülfam potasyum verilmiş ve iki grup arasinda ortalama bakteri sayılarında anlamlı bir fark görülmemiş olup, Bacteroidetesin Firmicutese oranının değişmediği tespit edilmiştir (Frankenfeld vd., 2015).

\section{Asesülfam-potasyum (Ace-K)}

1967 yllında keşfedilmiş olup 1988 yilında FDA tarafindan onaylanan Ace-K, sükrozdan 200 kat daha tatlı olan asidik bir siklik sülfonamid türevidir (Özdemir vd., 2014). ADI değeri 15 $\mathrm{mg} / \mathrm{kg}$ dozdur (Cao vd., 2020). Ace-K'nin genotoksik olduğu ve bağırsak bakterileri tarafindan glukoz fermantasyonunu inhibe edebileceği düşünülmektedir (Bandyopadhyay vd., 2008). Yapılan bir çalışmada da Ace-K alımı DNA hasarını artırmıştır (Fındıklı ve Türkoğlu, 2014).

Ace-K tatlandırıcısının mikrobiyota üzerine etkisini değerlendirmek üzere yapılan çalışmaların sonuçları çelişkilidir. Örneğin, 4 hafta boyunca farelerde $37,5 \mathrm{~g}$ günlük doz Ace-K takviyesi sonras1, erkek farelerin vücut ağırllğında ve Bacteroidetes, Sutterella ve Anaerostipes sayllannda önemli ölçüde artış görülmüştür. Dişi farelerde ise vücut ağırlı̆̆ında önemli bir değişiklik olmazken, 2-oleotrigliserit, süksinik asit ve D-laktik asit gibi birçok bakteriyel metabolitte azalma gözlenmiştir.
Oxalobacteraceae, Clostridium, Lactobacillus ve Ruminococcaceae azalırken, Mucispirillum türlerinde artış görülmüştür. Ek olarak, Ace-K'ya maruz kalan dişi farelerde LPS sentezinde yer alan genlerin ekspresyonu da artmıştır (Bian vd., 2017b). Başka bir çalışmada ise farelere 8 hafta 15 $\mathrm{mg} / \mathrm{kg}$ günlük doz sükraloz veya Ace-K takviyesi sonucu Ace-K'nın bağırsak mikrobiyotasını değiştirmediği sonucuna varılmıştır (Uebanso vd., 2017).

\section{Sükraloz (splenda)}

1976 yllında keşfedilmiş olan sükraloz, 1999 yilında FDA tarafindan onaylanmıştır (Özdemir vd., 2014). Sükroza göre 320-1000 kat daha tatlı olan sükraloz, klorlu bir disakkarittir. ADI değeri $15 \mathrm{mg} / \mathrm{kg}$ doz şeklindedir (Cao vd., 2020). Sükraloz tüketiminin glukoz intoleransını arturdığını gösteren çalışmalar mevcut olsa da (Pepino vd., 2013; Pepino vd., 2018) etkisi olmadığ1 da gösterilmiştir (Grotz vd., 2017). Güncel bir derleme sükraloz tüketiminin sağlık üzerine etkisini değerlendirmiş ve çalışmalar arasında farklılık saptamıştır. $\mathrm{Bu}$ nedenle tüketiminin fayda-zarar bağlamında değerlendirilmesi kesin değildir (Ahmad vd., 2020).

Sükralozun mikrobiyota üzerine etkisini değerlendiren çalışmalara bakıldığında; farelere 3 gün $\% 20$ 'lik sükraloz ya da sorbitol takviyesi sonucu, sorbitol takviyesi toplam aerobik veya anaerobik bakteri, aerobik Streptococcus ve maya sayısında önemli bir değişikliğe yol açmamışken, sükraloz tüketimi dışkıdaki toplam aerobik ve anaerobik bakterileri azaltmıştır (Salminen vd., 1986). Başka bir çalışmada, farelere 12 hafta boyunca oral gavaj yoluyla 100, 300, 500 veya $1000 \mathrm{mg} / \mathrm{kg}$ günlük doz splenda takviyesi yapılmış ve Bifidobacterium, Lactobacillus ile Bacteroidetes türlerinde yüksek sayıda azalma ve Enterobacteriaceae saylannda daha az seviyede bir azalma olduğunu bildirilmiştir (Abou-Donia vd., 2008). Farelere 8 hafta $15 \mathrm{mg} / \mathrm{kg}$ günlük doz sükraloz ve Ace-K takviyesi sonucu sükralozla beslenen farelerde Clostridium Cluster XIVa sayılarında azalma gözlenmiştir (Uebanso vd., 2017). Fareler üzerinde yapilan başka bir çalışmada, 6 ay boyunca $0,1 \mathrm{ml} / 1$ sükraloz 
takviyesi sonucu; 3 ay sonunda, Ruminococcus, Bacillales, Peptostreptococcaceae, Staphylococcus ve Anaerostipes popülasyonlar1 azalırken; 6 ay sonunda, Christensenellaceae, Clostridiaceae, Akkermansia, Roseburia ve Turicibacter popülasyonlar1 artmış; Erysipelotrichaceae, Dehalobacterium, Streptococcus ve Ruminococcus popülasyonlarında azalma gösterilmiştir (Bian vd., 2017a). Farelere doz artış1 yapılarak, ilk 6 hafta $1,08 \mathrm{mg} / \mathrm{ml}$, sonraki 6 hafta $3,5 \mathrm{mg} / \mathrm{ml}$ ve diğer 6 hafta $35 \mathrm{mg} / \mathrm{ml}$ splenda takviyesi verilen bir çalışmada, ateroskleroz oluşumunda rolü olan myeloperoksidaz (MPO) enzim aktivitesinde artış olduğunu görülmüştür. Ayrıca splenda, tüm farelerde Proteobacteria sayılarının artışını sağlayarak disbiyozise yol açmıştır (RodriguezPalacios vd., 2018). Yine farelerde 8 hafta boyunca suda çözünmüş $\% 2,5$ sükraloz takviyesi sonucu mikrobiyotada Firmicutes türlerinde artış görüldüğü rapor edilmiştir (Wang vd., 2018). İnsanlar üzerinde yapılan bir çalışmada ise, 34 sağlıklı erkek iki gruba ayrılmış ve bir gruba 7 gün boyunca, $780 \mathrm{mg}$ günlük doz sükraloz içeren kapsül takviyesi diğerine plasebo verilmiştir. İnsülin yanıtına göre sinıflama yapıldığında, sükraloz içeren kapsül takviyesi, insülin yanıtı düşük olan bireylerde Bacteroidetes sayılarında artış, Firmicutes sayılarında azalmaya yol açmıştr (Thomson vd., 2019).

\section{Diğer tatlandırıcılar}

Neotam, şekerden 7000 ile 13.000 kat daha tatlı olan, kimyasal olarak aspartama benzeyen bir tatlandirıcidir (Fitch ve Keim, 2012) ve 2002 yılında FDA tarafindan onaylanmıştır (Özdemir vd., 2014). Neotamın ADI değeri $2 \mathrm{mg} / \mathrm{kg}$ şeklindedir (Cao vd., 2020). Çalışmalara göre neotamın glukoz intoleransı üzerine olumsuz bir etkisi görülmemiştir (Mayhew vd., 2003; Sanyaolu vd., 2019). Mikrobiyota üzerine etkisini değerlendiren bir çalışmada, farelere 4 hafta boyunca günlük $0,75 \mathrm{mg} / \mathrm{kg}$ günlük doz neotam takviyesi sonucu, farelerde Bacteroidetes sayılarında artış görülürken, Firmicutes sayllarında önemli bir azalma gözlenmiştir. Neotam ile beslenen farelerde on iki bakteri türünün popülasyonunda artış olmuş ve neotam tüketmeyen gruba göre, Ruminococcaceae ve Lachnospiraceae üyeleri olan Ruminococcus, Oscillospira, Dorea ve Blautia bakteri popülasyonlarında önemli bir azalma olduğunu bildirilmiştir (Chi vd., 2018).

Stevia, şekerden 250 kat daha tatlı olup, 2008 yllında FDA tarafindan onaylanmıştır ve besinlerin içerik listelerinde rebiana, rebaudiozit A/reb A, steviosid veya steviol glikozitler olarak da bilinmektedir (Özdemir vd., 2014). Stevianın vücut ağırllğ1 yönetimi, diyabet ve iştah kontrolündeki rolü hakkında sınırlı sayıda araştırma mevcuttur (Serrano ve Riebl, 2019). Mikrobiyota üzerine etkisini değerlendirmek için yapılan in vitro bir çalışmada, $1 \mathrm{mg} / \mathrm{ml}$ steviosid ve rebaudiozit A takviyesi, insan bağırsak mikroflora bileşiminde önemli bir değişikliğge yol açmamıștır; bununla birlikte, steviosidin toplam aerobik bakteriler üzerinde hafif bir inhibe edici etkiye sahip olduğu görülürken, rebaudiozit A'nın toplam aerobik bakteriler ve koliformların çoğalmasını etkilediği gösterilmiştir (Gardana vd., 2003). Başka bir in vitro çalışmada ise $40 \mathrm{mg}$ sodyum siklamat, sükraloz, sodyum sakkarin ve steviol tozu mikroorganizma sayısını $10^{9}$ genom/ml'ye, steviol ve esmer şeker, steviol kapsülü ve beyaz şeker takviyesi ise $10^{8}$ genom/ml'ye düşürmüştür. Ayrıca BacteroidetesPrevotella-Porphyromonas gruplar1 steviol kapsül tüketimi ile azalmışır. Sodyum sakkarin, steviol tozu ve kapsülü ile steviol ve esmer şeker takviyesi Firmicutes türlerini artırmıs, sodyum siklamat, sükraloz ve beyaz şeker tüketimi ise azaltmıştır (Vamanu vd., 2019).

Yukarıdaki çalışmalar incelendiğinde, hayvan modellerinde gıda katkı maddelerinin tüketiminin disbiyozise yol açabileceği gösterilmiştir. Tatlandırıcılar ile yapılmış çalışmalarda genellikle anaerobik bakterilerde artış görülmüştür (Anderson ve Kirkland, 1980; Gardana vd., 2003; Palmnäs vd., 2014; Suez vd., 2015; Bian vd., 2017b). Özellikle Bacteroidetes, Clostridium leptum, Lactobacillus türleri artış gösteren bakteri grupları iken, tam tersini gösteren çalışmalar da mevcuttur (Naim vd., 1985; Abou-Donia vd., 2008; Daly vd., 2014). Yapılan çalışmalar farklı hayvan modelleri üzerinde olduğu için farklı sonuçlar elde edilmiş olabilir. Yine tatlandirıcilar, proinflamatuar etki gösteren biyobelirteçleri de etkilemektedirler (Mallett vd., 1985; Bian vd., 2017c). İnsanlarda 
sakkarin tüketimi, tüm katılımcılarda olmasa da bazılarında glukoz homeostazını bozmuştur (Suez vd., 2014). Yine bir diğer çalışmada hayvan çalışmalanına benzer olarak Bacteroidetes seviyelerinde artıs, Firmicutes seviyelerinde azalma meydana gelmiştir (Thomson vd., 2019).
Mikrobiyota üzerine etkileri genellikle hayvan modelleri ile sınırlı kalsa da çalışmaların çoğunda tatlandırıcilanın doku ve organları olumsuz yönde etkilediği görülmektedir. Çizelge 1'de tatlandirıciların mikrobiyota üzerine etkisini değerlendiren çalışmaların özetlerini verilmiştir.

Çizelge 1. Tatlandırıcıların mikrobiyota üzerine etkisini değerlendiren çalışmaların özetleri

\begin{tabular}{|c|c|c|c|}
\hline $\begin{array}{l}\text { Çalışma } \\
\text { grubu }\end{array}$ & $\begin{array}{l}\text { Kullanilan GKM, süresi ve } \\
\text { dozu }\end{array}$ & Sonuçlar & Kaynak \\
\hline In vitro & $\begin{array}{l}20 \text { saat, } \% 2,5 \text { sodyum } \\
\text { sakkarin }\end{array}$ & Lactobacillus ve E. coli popülasyonlannda azalma & Naim vd., 1985 \\
\hline In vitro & $\begin{array}{l}1 \mathrm{mg} / \mathrm{ml} \text { steviosid ve } \\
\text { rebaudiozit } \mathrm{A}\end{array}$ & $\begin{array}{l}\text { Steviosid toplam aerobik bakterilerde az düzeyde } \\
\text { azalma, rebaudiozit A toplam aerobik ve } \\
\text { koliformlann miktarında artış }\end{array}$ & $\begin{array}{l}\text { Gardana vd., } \\
2003\end{array}$ \\
\hline In vitro & $\begin{array}{l}40 \text { mg sodyum siklamat, } \\
\text { sükraloz, sodyum } \\
\text { sakkarin, steviol tozu, } \\
\text { steviol ve esmer şeker, } \\
\text { steviol kapsül, beyaz şeker }\end{array}$ & $\begin{array}{l}\text { Steviol kapsül, Bacteroidetes-Prevotella-Porphyromonas } \\
\text { türlerinde azalma; sodyum sakkarin, steviol tozu ve } \\
\text { kapsülü ile steviol ve esmer şeker, Firmicutes } \\
\text { türlerinde artış; sodyum siklamat, sükraloz ve beyaz } \\
\text { şeker Firmicutes türlerinde azalma }\end{array}$ & $\begin{array}{l}\text { Vamanu vd., } \\
2019\end{array}$ \\
\hline Fare & 10 gün, $\% 7,5$ sakkarin & Aerobik bakterilerde artış & $\begin{array}{l}\text { Anderson ve } \\
\text { Kirkland, } 1980\end{array}$ \\
\hline Fare & $\% 5$ ve $\% 7,5$ sakkarin & Propiyonat, bütirat ve valerat seviyelerinde azalma & $\begin{array}{l}\text { Anderson, } \\
1985\end{array}$ \\
\hline Fare & 20 hafta, $50 \mathrm{~g}$ sakkarin & $\begin{array}{l}\text { \%30-50 oraninda amonyak konsantrasyonunda ve } \\
\text { bakteriyel enzim aktivitelerinde azalma }\end{array}$ & $\begin{array}{l}\text { Mallets vd., } \\
1985\end{array}$ \\
\hline Fare & 40 gün, $\% 7,5$ sakkarin & $\begin{array}{l}\text { İndikan ve p-kresolün idrarla günlük atılımında 3-4 } \\
\text { kat artış }\end{array}$ & $\begin{array}{ll}\text { Lawrie vd., } \\
1985\end{array}$ \\
\hline Fare & $\begin{array}{l}3 \text { gün, } \% 20 \text { sorbitol ya da } \\
\text { sükroz }\end{array}$ & $\begin{array}{l}\text { Sorbitol tüketimi bakteriler üzerinde önemli bir } \\
\text { değişiklik göstermemiş, sükroz tüketimi dışkıdaki } \\
\text { toplam aerob ve anaerob sayılarında azalma }\end{array}$ & $\begin{array}{l}\text { Salminen vd., } \\
1986\end{array}$ \\
\hline Fare & $\begin{array}{l}12 \text { hafta, } 100,300,500 \\
\text { veya } 1000 \mathrm{mg} / \mathrm{kg} \text { splenda }\end{array}$ & $\begin{array}{l}\text { Bifidobacterium, Lactobacillus ile Bacteroidetes türlerinde } \\
\text { yüksek, Enterobacteriaceae türlerinde daha az seviyede } \\
\text { bir azalma }\end{array}$ & $\begin{array}{l}\text { Abou-Donia } \\
\text { vd., } 2008\end{array}$ \\
\hline Fare & $\begin{array}{l}8 \text { hafta, } 5-7 \mathrm{mg} / \mathrm{kg} / \text { gün } \\
\text { aspartam }\end{array}$ & Enterobacteriaceae ve Clostridium leptum sayılarında artış & $\begin{array}{l}\text { Palmnäs } \\
\text { vd.,2014 }\end{array}$ \\
\hline Domuz & $\begin{array}{l}2 \text { hafta, } \% 0,015 \text { sakkarin } \\
\text { ve neohesperidin } \\
\text { dihidrokalkon }\end{array}$ & $\begin{array}{l}\text { Fekal Lactobacillus miktarında ve bağırsak lümeninde } \\
\text { laktik asit konsantrasyonlarında artış }\end{array}$ & Daly vd., 2014 \\
\hline Fare & $\begin{array}{l}11 \mathrm{hafta}, 0,1 \mathrm{mg} / \mathrm{ml} \\
\text { sodyum sakkarin, sükraloz } \\
\text { veya aspartam }\end{array}$ & $\begin{array}{l}\text { Sodyum sakkarin tüketimi Bacteroidetes ve baz1 } \\
\text { Clostridium türlerinde artsş }\end{array}$ & Suez vd., 2015 \\
\hline Domuz & $\begin{array}{l}2 \text { hafta, } \% 0,015 \text { sakkarin } \\
\text { ve neohesperidin } \\
\text { dihidrokalkon }\end{array}$ & Lactobacillus popülasyonunda oldukça yüksek bir artış & Daly vd., 2016 \\
\hline Fare & 6 ay, $0,1 \mathrm{ml} / 1$ sükraloz & 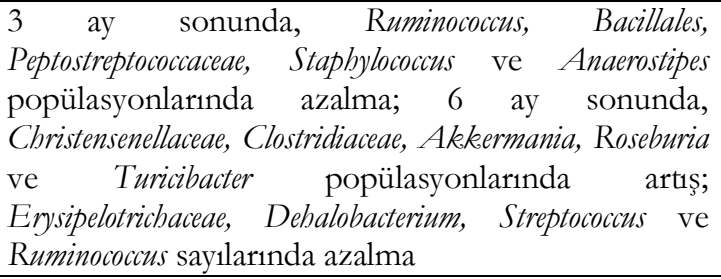 & Bian vd., 2017a \\
\hline
\end{tabular}




\begin{tabular}{|c|c|c|c|}
\hline Fare & 4 hafta, 37,5 g/gün Ace-K & $\begin{array}{l}\text { Erkek farelerde Bacteroidetes, Sutterella ve Anaerostipes } \\
\text { sayılarında artsş; diși farelerde Oxalobacteraceae, } \\
\text { Clostridium, Lactobacillus ve Ruminococcaceae azalma ile } \\
\text { Mucispirillum sayılarında artış }\end{array}$ & Bian vd., 2017b \\
\hline Fare & 6 ay, $0,3 \mathrm{mg} / \mathrm{ml}$ sakkarin & iNOS ve TNF- $\alpha$ aktivitelerinde ile LPS’lerde artış & Bian vd., 2017c \\
\hline Fare & $\begin{array}{l}8 \mathrm{hafta}, 15 \mathrm{mg} / \mathrm{kg} \\
\text { sükraloz ya da Ace-K }\end{array}$ & $\begin{array}{l}\text { Ace-K tüketimi bağırsak mikrobiyotasını } \\
\text { değiştirmemiş, sükraloz tüketimi } \\
\text { XIVa sayıliarında azalma }\end{array}$ & $\begin{array}{l}\text { Uebanso vd., } \\
2017\end{array}$ \\
\hline Fare & $\begin{array}{l}\text { Art arda gelen } 6 \mathrm{hafta}, \\
1,08,3,5 \text { ve } 35 \mathrm{mg} / \mathrm{ml} \\
\text { splenda }\end{array}$ & MPO aktivitesinde ve Proteobacteria sayılarında artış & $\begin{array}{l}\text { Rodriguez- } \\
\text { Palacios vd., } \\
2018\end{array}$ \\
\hline Fare & 8 hafta, $\% 2,5$ sükraloz & Firmicutes popülasyonunda artış & Wang vd., 2018 \\
\hline Fare & $\begin{array}{l}4 \text { hafta, } 0,75 \mathrm{mg} / \mathrm{kg} / \text { gün } \\
\text { neotam }\end{array}$ & $\begin{array}{l}\text { Bacteroidetes sayılarında artıs, Firmicutes sayılarında } \\
\text { azalma }\end{array}$ & Chi vd., 2018 \\
\hline Fare & $\begin{array}{l}17 \text { hafta, } \% 0,3 \text { sodyum } \\
\text { sakkarin ve sodyum } \\
\text { siklamat içeren yoğurt }\end{array}$ & Mikrobiyotada önemli bir değişikliğe yol açmamıstır & $\begin{array}{l}\text { Falcon } \\
2020\end{array}$ \\
\hline İnsan & $\begin{array}{l}\text { Besin tüketim sıklığı ile } \\
\text { tatlandırıcı tüketim } \\
\text { durumu }\end{array}$ & $\begin{array}{l}\text { Tatlandırıcı tüketimi ile Enterobacteriaceae, } \\
\text { Deltaproteobacteria ve Actinobacteria popülasyonlarında } \\
\text { artış }\end{array}$ & Suez vd., 2014 \\
\hline İnsan & $\begin{array}{l}4 \text { gün, } 5,3-112 \mathrm{mg} / \text { gün } \\
\text { aspartam ve } 1,7-33,2 \\
\text { mg/gün Ace-K }\end{array}$ & $\begin{array}{l}\text { Aspartam ve Ace-K tüketimi Bacteroidetesin Firmicutes } \\
\text { oranını etkilemedi }\end{array}$ & $\begin{array}{l}\text { Frankenfeld } \\
\text { vd., } 2015\end{array}$ \\
\hline İnsan & $\begin{array}{l}7 \text { gün, } 780 \mathrm{mg} / \text { gün } \\
\text { sükraloz içeren kapsül }\end{array}$ & $\begin{array}{l}\text { İnsülin yanıtı düşük olan bireylerde Bacteroidetes } \\
\text { seviyelerinde artış ve Firmicutes seviyelerinde azalma }\end{array}$ & $\begin{array}{l}\text { Thomson vd., } \\
2019\end{array}$ \\
\hline
\end{tabular}

GKM: g1da katk1 maddesi, mg: miligram, ml: mililitre, kg: kilogram, 1:litre, Ace-K: Asesülfam potasyum, iNOS: indüklenebilir nitrik oksit sentaz, TNF- $\alpha$ : tümör nekroz faktör- $\alpha$, LPS: lipopolisakkarit, MPO: myeloperoksidaz

\section{EMÜLSİFIYYER OLARAK KULLANILAN GIDA KATKI MADDELERIN MİKROBIYYOTA ÜZERINNE ETKİİ}

Emülsifiyerler gidanın dokusunu ve tadını iyileştirmeye, ürün stabilitesini artırmaya ve raf ömrünü uzatmaya yardımcı olarak kullanılan gıda katk1 maddeleridir (Halmos vd., 2019). Baz1 emülsiyonlaştırıcılar, gidalarda doğal olarak bulunur ve diğerleri, karboksimetil selüloz (CMC) ve polisorbat 80 (P80) gibi doğal olarak oluşan bileşiklerden sentezlenir. Son yllarda, artan çalışmalar gıda emülsiyonlaştırıcılarının bağırsak mikrobiyotasını etkileyebileceğini, göstermiştir (Swidsinski vd., 2009; Chassaing vd., 2015; Chassaing vd., 2017; Singh vd., 2016; Viennois vd., 2017; Furuhashi vd., 2020).

\section{Karboksi metil selüloz (CMC)}

CMC, kloroasetik asit ve alkali ile işlenmiş odun hamurundan elde edilen bir selüloz türevidir (Cao vd., 2020). CMC'nin toksik olmadığ1 düşünülmektedir fakat bir fare çalışmasında ön ayak kavrama gücü ile ölçülen motor dayanıklılığını olumsuz yönde etkilemiştir (Isa vd., 2019). İnsanlarda toksisitesiyle ilgili bir çalışmaya rastlanmadığ 1 için etkileri belirsizdir. Mikrobiyota üzerine etkisini değerlendiren çalışmalara bakıldığında CMC'nin doku ve organları olumsuz yönde etkileyebileceği düşünülebilir (Swidsinski vd., 2009; Viennois vd., 2017). Farelere 3 hafta boyunca \%2'lik CMC çözeltisi takviyesi verilmesi sonucu, bağırsak mukozasında daha fazla sayıda bakteri büyümesi gözlenmiş ve bakterilerin lieberkühn kriptalarının (ince bağırsak ekzokrin bez tipleri) aşağısına doğru göçe başladıklarını bildirilmiştir (Swidsinski vd., 2009). Başka bir çalışmada ise farelere 13 hafta boyunca \%1'lik CMC veya P80 takviyesi verilmiş ve 13 hafta sonunda Flagellin popülasyonu ile LPS'lerde artış gösterilmiştir. Bu çalışma, CMC'nin proliferasyon ve apoptoz arasındaki dengeyi değiştirdiğini, kolonda pro-inflamatuar bir ortam oluşturduğunu ve bunu koruduğunu, böylece karsinojenezi teşvik ettiğini öne sürmüştür (Viennois vd., 2017). 


\section{Polisorbat 80 (P80)}

P80, polietoksillenmiş sorbitan ve oleik asitten türetilen bir emülgatördür. P80 için ADI değeri $25 \mathrm{mg} / \mathrm{kg}$ şeklindedir (Cao vd., 2020). İnsanlarda tek başına P80 verilmesi sonucu sağlık üzerine etkisini değerlendiren bir çalışmaya rastlanmamıştır. Mikrobiyota üzerine etkisini değerlendiren çalışmalara bakıldığında; in vitro bir çalışmada $\% 0,1, \% 0,25, \% 0,5$ ve $\% 1^{\prime}$ lik bir nihai konsantrasyonda CMC veya P80 takviyesinin proinflamatuar olan bioaktif Flagellin seviyelerinde artış gösterdiği rapor edilmiştir (Chassaing vd., 2017). Farelere 12 hafta boyunca suda çözünmüş $\% 1$ lik CMC veya P80 takviyesi ise 12 hafta sonunda düşük dereceli inflamasyon ve obezite ya da metabolik sendromun gelişmesinde artışa yol açmışır. Ayrıca 12 haftanın sonunda, P80 alımının farelerdeki toplam dışkı bakterileri üzerinde anlamlı bir etkisi olmadığ1 görülmüş fakat P80 bağırsak mukus kalınlı̆̆ını azaltarak, bakteriler ve epitel hücreler arasındaki temas1 artırmış ve bağırsak adezyon florası ve dışk1 bakteri kompozisyonunda değişikliklere neden olmuştur. P80 ayrıca bağırsak geçirgenliğinin, LPS'lerin ve Flagellin seviyelerinin artışına yol açmıştır (Chassaing vd., 2015). Başka bir çalışmada 4 hafta, \%1'lik P80 takviyesi alan farelerde, Gram pozitif bakterilerin sayısında önemli ölçüde artış meydana gelmiş ve bağırsaktaki bakteri metabolitlerinin enterohepatik dolaşımı yoluyla non alkolik yağlı karaciğer hastalığına yol açtı̆̆ını bulunmuştur. Bacteroidetes popülasyonunun azalması dişında, Salmonella spp. Helicobacter, Clostridium, Campylobacter jejuni ve Porphyromonadaceae popülasyonları da artış göstermiş̧tir. Ayrıca P80 alan gruptaki farelerin kolon ve dişkilarında yüksek Lipokalin 2 (LCN2) seviyeleri, artmış bağırsak geçirgenliği ve kronik bağırsak iltihabı ile ilişkili artmış Flagellin ve LPS seviyeleri gösterilmiştir (Singh vd., 2016). Fareler üzerinde yapılan başka bir çalışmada ise 8 hafta \%1'lik P80 takviyesi, $\gamma$-proteobakteri sayılarını artırmış ve ince bağırsakta $\alpha$ bakteri çeşitliliğini azaltmıştır. Kolonda ise $\alpha$ çeşitliliğinde bir azalma gözlenmemiştir. Ayrıca P80 takviyesi, indometasin kaynaklı ince bağırsak lezyonlarının şiddetini artırmış ve İnterlökin-1 Beta (IL-1 $\beta$ ) ekspresyonunda da artış sağlamıştır. Proteus mirabilis ve E. Coli popülasyonunda artış meydana gelmiştir (Furuhashi vd., 2020).

Literatürde, mikrobiyota üzerine etkisi en çok değerlendirilen ikinci grupta yer alan emülsifiyer gıda katkı maddeleri ile yapılan çalışmalañn sonuçları, gıda katk1 maddelerinin bağırsak mikrobiyotasını doğrudan değiştirebileceği, hücre proliferasyonu ve apoptozun sinyal yollarını etkileyebileceği ve bağırsak iltihaplanması ile bozulmuş metabolik homeostaza yol açabileceğini göstermiştir (Swidsinski vd., 2009; Chassaing vd., 2015; Furuhashi vd., 2020). Özellikle LPS ve Flagellin seviyelerinde artışa yol açarak bu etkilerini göstermektedirler (Chassaing vd., 2015; Singh vd., 2016; Chassaing vd., 2017; Viennois vd., 2017). $\mathrm{Bu}$ grupta yapilan çalışmalar fare modelleri ile sınırlı kalmıştır ve insanlar üzerinde yapılan bir çalışmaya rastlanmaması insan bağırsak mikrobiyotası üzerine etkilerini değerlendirme konusunda belirsizliğini korumaktadır. Çizelge 2'de emülsifiyer olarak kullanılan gida katk1 maddelerinin mikrobiyota üzerine etkisini değerlendiren çalışmaların özetleri verilmiştir.

\section{DİĞER GIDA KATKI MADDELERINIIN MİKROBİTOYA ÜZERİNE ETKİSİ}

\section{Benzoik asit (BA)}

BA $\left(\mathrm{C}_{7} \mathrm{H}_{6} \mathrm{O}_{2}\right)$, benzen halkasına doğrudan bağlı bir karboksilik grup ile en basit aromatik karboksilik asittir (Öztürkcan ve Acar, 2017; Del Olmo vd., 2017). Gidalarda yaygin olarak kullanılan BA ve tuzlan antimikrobiyal amaçla kullanılmaktadır. Bunun yanı sıra, asit formuna göre BA tuzları daha fazla kullanılır, çünkü BA tuzlarının sudaki çözünürlükleri yüksektir (Öztürkcan ve Acar, 2017). BA ve tuzlar1 orofasiyal granülomatozisin (yüzde, ağız ve çevresinde granülasyon yapan bir grup hastalık) alevlenmesi ile ilişkilendirilmiştir ve bu nedenle kronik uygulamalarda, kronik inflamatuar hastalıklardan etkilenen hastalar için benzoat içermeyen diyet önerilmektedir (Campbell vd., 2011). BA ayrıca sindirim mukoza zannda tahrişe neden olabilir ve ADI değerinden daha yüksek dozlarda alınması (yani art arda beş gün boyunca $1000 \mathrm{mg} / \mathrm{kg}$ ) bulantı, baş ağrısı, yemek borusu yanması ve sindirim kullanım katsayısının azalmasina neden olabilir (Iammarino vd., 2011). 
Çizelge 2. Emülsifiyerlerin mikrobiyota üzerine etkisini değerlendiren çalışmaların özeti

\begin{tabular}{|c|c|c|c|}
\hline $\begin{array}{l}\text { Çalışma } \\
\text { grubu }\end{array}$ & $\begin{array}{l}\text { Kullanilan GKM, süresi } \\
\text { ve dozu }\end{array}$ & Sonuçlar & Kaynak \\
\hline In vitro & $\begin{array}{l}\% 0,1 \% 0,25, \% 0,5 \text { ve } \\
\% 1 \mathrm{P} 80\end{array}$ & Tüm dozlarda Flagellin seviyelerinde artş & $\begin{array}{l}\text { Chassaing } \\
\text { vd., } 2017\end{array}$ \\
\hline Fare & 3 hafta, $\% 2$ CMC & $\begin{array}{l}\text { Bağırsak mukozasında daha fazla sayıda bakteri } \\
\text { artışı }\end{array}$ & $\begin{array}{l}\text { Swidsinksi } \\
\text { vd., } 2009\end{array}$ \\
\hline Fare & $\begin{array}{l}12 \text { hafta, \%1 CMC ya da } \\
\text { P80 }\end{array}$ & $\begin{array}{l}\text { P80 tüketenlerde bağırsak geçirgenliği, LPS ve } \\
\text { Flagellin seviyelerinde artış }\end{array}$ & $\begin{array}{l}\text { Chassaing } \\
\text { vd., } 2015\end{array}$ \\
\hline Fare & 4 hafta, $\% 1$ P80 & $\begin{array}{l}\text { Bacteroidetes'lerde azalma, Salmonella spp., } \\
\text { Helicobacter, Clostridium, Campylobacter jejuni, } \\
\text { Porpbyromonadaceae, Flagellin ve LPS'de artış }\end{array}$ & $\begin{array}{l}\text { Singh vd., } \\
2016\end{array}$ \\
\hline Fare & $\begin{array}{l}13 \text { hafta, } \% 1 \text { CMC ya da } \\
\text { P80 }\end{array}$ & $\begin{array}{l}\text { CMC tüketenlerde Flagellin popülasyonu ile } \\
\text { LPS’lerde artış }\end{array}$ & $\begin{array}{l}\text { Viennos } \\
\text { vd., } 2017\end{array}$ \\
\hline Fare & 8 hafta $\% 1$ P80 & $\begin{array}{l}\gamma \text {-proteobakteri'lerde artıs, ince bağırsakta } \alpha \\
\text { bakteri çeşitliliğinde azalma, Proteus mirabilis ve } \\
\text { E.coli popülasyonunda artış }\end{array}$ & $\begin{array}{l}\text { Furuhashi } \\
\text { vd., } 2020\end{array}$ \\
\hline
\end{tabular}

GKM: g1da katkı maddesi, CMC: karboksimetil selüloz, P80: polisorbat 80, LPS: lipopolisakkarit

Domuzlara 35 gün 5 ve $10 \mathrm{~g} / \mathrm{kg}$ günlük doz BA ya da $12 \mathrm{~g} / \mathrm{kg}$ günlük doz potasyum diformat takviyesi, bakteri sayısında azalmaya yol açmıştır. Midede toplam aerobik, anaerobik, laktik asit oluşturan ve Gram negatif bakteri sayıları; duodenumda Gram negatif bakteri sayısını ve ileumda doza bağlı bir şekilde toplam aerobik bakteri sayısını azalttığı bildirilmiştir (Kluge vd., 2006). Tavuklarda yapılan bir çalışmada, 42 gün boyunca $2,5,5$ ve $7,5 \mathrm{~g} / \mathrm{kg}$ günlük doz $\mathrm{BA}$ takviyesi sonucu, her grupta laktik asit bakteri sayılarında artış görülürken, bu artış $7,5 \mathrm{~g} / \mathrm{kg}$ günlük doz alanlarda daha yüksek olmuştur (Józefiak vd., 2010). Domuzlara 2 hafta $5 \mathrm{~g} / \mathrm{kg}$ günlük doz BA ile $0,40,80 \mathrm{~g} / \mathrm{kg}$ günlük doz inülin takviyesi sonucu bakteri çeşitliliğinde artış saptanmış ve sadece BA alan grupta laktik asit seviyelerinde azalma gözlenmiştir (Halas vd., 2010). Domuzlara 42 gün boyunca $5000 \mathrm{mg} / \mathrm{kg}$ günlük doz BA takviyesi sonucu ise bağırsaklarda Bifidobacterium ve Bacillus sayılarında artış gözlenirken, E.coli sayılarında azalma görülmüştür (Diao vd., 2014). Yine domuzlarda yapılan başka bir çalışmada domuzlar 4 gruba ayırmışlardır: 1 . grup kontrol diyeti ile beslenen grup, 2 . grup kontrol $+1000 \mathrm{mg} / \mathrm{kg} \mathrm{BA}+100 \mathrm{mg} / \mathrm{kg}$ timol, 3 . grup kontrol $+1000 \mathrm{mg} / \mathrm{kg} \mathrm{BA}+200 \mathrm{mg} / \mathrm{kg}$ timol ve 4. grup kontrol $+2000 \mathrm{mg} / \mathrm{kg} \mathrm{BA}+100$ $\mathrm{mg} / \mathrm{kg}$ timol takviyesi almıştır. Özellikle 3. grupta daha yüksek olmak üzere tüm BA ve timol takviyesi alan gruplarda Lactobacillus spp. seviyeleri ile yine tüm gruplarda benzer oranda Bacillus spp. seviyelerinde artış meydana gelmiştir. Ayrıca 3. grupta yüksek oranda bütirik asit seviyesi gözlenmiştir (Diao vd., 2015).

Yine antimikrobiyal amaçla kullanılan diğer gida katk1 maddeleri olan sodyum benzoat, sodyum nitrat ve potasyum sorbatin da mikrobiyota üzerine etkilerini değerlendiren Hrncirova ve ark. tarafindan yapılmış çalışmalar mevcuttur ( Hrncirova vd., 2019a; Hrncirova vd., 2019b). In vitro olarak $1 \mathrm{mg} / \mathrm{ml}$ sodyum benzoat, sodyum nitrat, potasyum sorbat takviyesi sonucu, Clostridium tyrobutyricum veya Lactobacillus paracasei gibi bilinen anti-inflamatuar özelliklere sahip bağırsak bakterilerinin, Bacteroides thetaiotaomicron veya Enterococcus faecalis gibi bilinen proinflamatuar veya kolitojenik özelliklere sahip bakterilerden bu katk1 maddelerine daha duyarl1 olduklarını göstermişlerdir (Hrncirova vd., 2019a). Farelere sodyum benzoat (4,8 $\mathrm{mg} / \mathrm{kg} /$ gün), sodyum nitrit $(0,36 \mathrm{mg} / \mathrm{kg} /$ gün $)$ ve potasyum sorbat (19 $\mathrm{mg} / \mathrm{kg} /$ gün) takviyesi sonucu bağırsak mikrobiyal çeşitliliğinin azalma ile özellikle bu durum Clostridiales sayılarının azalmasina ve Proteobacteria sayılarının artmasina yol açmışır (Hrncirova vd., 2019b). 
Görüldügü üzere antimikrobiyal amaçla kullanılan g1da katk1 maddelerinden olan BA ile sodyum nitrat ve potasyum sorbatın mikrobiyota üzerine etkisini değerlendiren çalışmaların sonuçları oldukça çelişkilidir. Bu grupta ki çalışmaların da çoğu benzer şekilde anaerobik bakterilerde artş̧ ve laktik asit oluşturan bakterilerde azalma gösterirken (Kluge vd., 2006; Halas vd., 2010; Irwin vd., 2017; Hrncirova vd., 2019a), tersini gösteren çalışmalar da mevcuttur (Józefiak vd., 2007; Diao vd., 2015). Ayrıca bu konuda yapılmış insan çalışmasına rastlanmaması, antimikrobiyal olarak kullanilan g1da katk1 maddelerinin mikrobiyota üzerine etkinliğini değerlendirmeyi kısıtlamaktadır.

\section{Monosodyum glutamat (MSG)}

MSG lezzet artıricı olarak ev yemekleri ile ticari ürünlerde en yaygin kullanilan gida katk1 maddelerinden biridir (Lindemann vd., 2002; Öztürkcan ve Acar, 2017). MSG’nin ADI değeri $30 \mathrm{mg} / \mathrm{kg}$ doz şeklindedir (Lindemann vd., 2002). MSG'nin toksik etkileri olarak obezite ve metabolik sendrom gibi kronik hastalıklara yol açabileceğine dair yaygın bir inanç bulunmaktadır (Niaz vd., 2018; Peng vd., 2018). Bu doğrultuda yapılan bazı çalışmalar MSG'nin doku ve organları olumsuz yönde etkilediğini göstermiştir (Ortiz vd., 2006; Matysková vd., 2008; Eweka vd., 2010).

Domuzlarda yapilan bir çalışmada, MSG ya da yüksek yağlı diyet tüketiminin mikrobiyota üzerindeki etkileri incelenmiş ve hem MSG hem de yüksek yağ tüketimi, gastrointestinal sistemde enerji ekstraksiyonu ile ilgili bakterilerin farklı yollarla kolonizasyonlarını artırmıştır. MSG, Faecalibacterium prausnitzii ve Roseburia türlerinin popülasyonunu artır1rken, yüksek yağ kolon ve diğer bağırsak segmentlerinde Prevotella popülasyonunu artırmıştır (Feng vd., 2015). İnsanlarda 2 g günlük doz MSG takviyesinin etkisini değerlendirilen bir çalışmada, 4 hafta sonunda MSG takviyesinin mikrobiyota yapisı ve fonksiyonunu önemli derecede etkilemediği bulunmuştur (Peng vd., 2018).

Umami tad olarak değerlendirilen ve artık hemen hemen herkesin bildiği MSG'nin mikrobiyota üzerine etkisini değerlendiren çalışmalar kullanım yaygınlığının tersine oldukça sınırlı olup, çelişkili sonuçlara rastlanmıştır (Feng vd., 2015; Peng vd., 2018). Çalışmaların farklı modeller üzerinde yürütülmesi ve az sayıda olmalan nedeniyle konunun aydınlatılabilmesi adına daha fazla çalışmaya ihtiyaç vardır.

\section{Sülfit}

Sülfit genellikle gidalarda mikrobiyal büyümeyi inhibe etmek ve rengi korumak için kullanıllır. ADI değeri $0,7 \mathrm{mg} / \mathrm{kg} \quad \mathrm{doz}$ şeklindedir (Öztürkcan ve Acar, 2017; Cao vd., 2020). Baz1 bireylerde sülfit içeren gıdaların ya da içeceklerin sindirilmesi, sülfür dioksitin solunması ve sülfit içeren ilaçların tedavi amacıyla kullanılması sonucunda, hayatı tehdit eden birçok tepkime olabilmektedir (Öztürkcan ve Acar, 2017). Mikrobiyota üzerine etkisini değerlendirmek için in vitro olarak yapılan bir çalışmada 10-3780 $\mathrm{mg} / \mathrm{kg} 6$ saatlik sülfit takviyesi sonucu, 250-500 $\mathrm{mg} / \mathrm{kg}$ 'da bakteri sayılarında azalma, 1000-3780 $\mathrm{mg} / \mathrm{kg}$ 'da Lactobacillus türleri üzerinde bakterisidal etkiler ve 6 saatlik maruziyetten sonra da 2000 $\mathrm{mg} / \mathrm{kg}$ 'da Streptococcus thermophilus üzerinde bakterisidal etkiler tespit edilmiştir (Irwin vd., 2017). Bununla birlikte, gerçek bağırsak ortamı daha karmaşıktır, bu nedenle sülfitin bağırsak mikrobiyomu üzerindeki spesifik etkilerini doğrulamak için başka hayvan deneylerine veya insanlar üzerinde yapılacak klinik çalışmalara ihtiyaç vardır.

\section{Titanyum dioksit $\left(\mathrm{TiO}_{2}\right)$}

$\mathrm{TiO}_{2}$, genellikle renklendirici olarak gidalara eklenen bir gida katk1 maddesidir (Pinget vd., 2019). Emilimi çok düşük miktarlarda olduğu için ADI değeri bulunmamaktadır (Hwang vd., 2019). $\mathrm{TiO}_{2}$ tüketiminin toksik etkileri olarak, oksidatif stresi ve inflamasyonu artırdığı, ayrıca genotoksik etkiler sergileyebileceğini gösterilmiştir (Pinget vd., 2019; Baranowska-Wójcik vd., 2020). $\mathrm{TiO}_{2}$ tüketiminin mikrobiyota üzerine etkisini değerlendiren bir çalışmada farelere 4 hafta 0,2 , 10 ve $50 \mathrm{mg}$ günlük doz $\mathrm{TiO}_{2}$ takviyesi sonucu, tüm dozlarda Lactobacillus ve Allobaculum türleri artmış; $50 \mathrm{mg}$ dozunda ise Parabacteroides türlerinde artş meydana gelmiştir. Ayrıca Adlercrentzia ve sinıflandırılmamış Clostridiaceae türleri 10 ve $50 \mathrm{mg} \mathrm{TiO}_{2}$ takviyesi ile önemli 
düzeyde azalmıştır (Pinget vd., 2019). Çalışma sonuçları $\mathrm{TiO}_{2}$ 'nin mikrobiyotayı olumsuz yönde etkilediğini gösterse de bu konu ile ilgili yapılan ilk ve güncel tarihli bir çalışma olmasından ötürü etkinliğini doğrulamak adına daha fazla çalışmaya ihtiyaç vardır. Çizelge 3’te diğer gıda katkı maddelerinin mikrobiyota üzerine etkisini değerlendiren çalışmaların özeti verilmiştir.

Çizelge 3. Diğer gıda katkı maddelerinin mikrobiyota üzerine etkisini değerlendiren çalışmaların özetleri

\begin{tabular}{|c|c|c|c|}
\hline $\begin{array}{l}\text { Çalışma } \\
\text { grubu }\end{array}$ & $\begin{array}{l}\begin{array}{l}\text { Kullanilan } \\
\text { süresi ve dozu }\end{array} \\
\end{array}$ & Sonuçlar & Kaynak \\
\hline$\dot{\text { In vitro }}$ & $\begin{array}{l}6 \text { saat, } 10-3780 \mathrm{mg} / \mathrm{kg} \\
\text { sülfit }\end{array}$ & $\begin{array}{l}250-500 \mathrm{mg} / \mathrm{kg} \text { 'da bakteri sayllarında azalma ile } \\
1000-3780 \mathrm{mg} / \mathrm{kg} \text { 'da Lactobacillus türlerinde } \\
\text { bakterisidal etkiler; } 6 \text { saatlik maruziyetten sonra } \\
\text { da } 2000 \mathrm{mg} / \mathrm{kg} \text { 'da Streptococcus thermophilus } \\
\text { üzerinde bakterisidal etkiler }\end{array}$ & $\begin{array}{l}\text { Irwin vd., } \\
2017\end{array}$ \\
\hline In vitro & $\begin{array}{l}1 \mathrm{mg} / \mathrm{ml} \text { sodyum } \\
\text { benzoat, sodyum nitrat } \\
\text { ve potasyum sorbat }\end{array}$ & Anti-inflamatuar bakterilerde artmış duyarlılık & $\begin{array}{l}\text { Hrncirava } \\
\text { vd., } \\
2019 \text { a }\end{array}$ \\
\hline Domuz & $\begin{array}{l}35 \text { gün, } 5 \text { ve } 10 \mathrm{~g} / \mathrm{kg} \\
\mathrm{BA} \text { ya da } 12 \mathrm{~g} / \mathrm{kg} \\
\text { potasyum diformat }\end{array}$ & $\begin{array}{l}\text { Midede toplam aerobik, anaerobik, laktik asit } \\
\text { oluşturan ve Gram negatif bakteri sayılarında } \\
\text { azalma; duodenumda Gram negatif bakteri } \\
\text { sayısını ve ileumda doza bağlı bir şekilde toplam } \\
\text { aerobik bakteri sayısında azalma }\end{array}$ & $\begin{array}{l}\text { Kluge } \\
\text { vd., } 2006\end{array}$ \\
\hline Tavuk & $\begin{array}{l}42 \text { gün, } 2,5,5 \text { ve } 7,5 \\
g / \mathrm{kg} \mathrm{BA}\end{array}$ & $\begin{array}{l}\text { Doza bağlı olarak laktik asit bakteri sayılarında } \\
\text { artış }\end{array}$ & $\begin{array}{l}\text { Józefiak } \\
\text { vd., } 2007\end{array}$ \\
\hline Domuz & $\begin{array}{l}2 \text { hafta } 5 \mathrm{~g} / \mathrm{kg} \text { BA ile } 0, \\
40,80 \mathrm{~g} / \mathrm{kg} \text { inülin }\end{array}$ & $\begin{array}{l}\text { Bakteri çeşitliğinde artış gösterilmiş olup, sadece } \\
\text { BA alan grupta laktik asit seviyelerinde azalma }\end{array}$ & $\begin{array}{l}\text { Halas vd., } \\
2010\end{array}$ \\
\hline Domuz & $\begin{array}{l}42 \text { gün, } 5000 \mathrm{mg} / \mathrm{kg} \\
\mathrm{BA}\end{array}$ & $\begin{array}{l}\text { Bifidobacterium ve Bacillus sayılarında artış, E.coli } \\
\text { sayılarında azalma }\end{array}$ & $\begin{array}{l}\text { Diao vd.,. } \\
2014\end{array}$ \\
\hline Domuz & $\begin{array}{l}42 \text { gün, } 1000 \text { ve } 2000 \\
\mathrm{mg} / \mathrm{kg} \mathrm{BA} \text { ile } 100 \text { ve } \\
200 \mathrm{mg} / \mathrm{kg} \text { timol }\end{array}$ & $\begin{array}{l}1000 \mathrm{mg} / \mathrm{kg} \mathrm{BA}+200 \mathrm{mg} / \mathrm{kg} \text { timol alan grupta } \\
\text { daha yüksek olmak üzere tüm BA ve timol } \\
\text { takviyesi alan gruplarda Lactobacillus spp. ve tüm } \\
\text { gruplarda Bacillus spp. seviyelerinde artış ile } 1000 \\
\mathrm{mg} / \mathrm{kg} \text { BA+200 mg/kg timol alan grupta bütirik } \\
\text { asit seviyelerinde artış }\end{array}$ & $\begin{array}{l}\text { Diao vd., } \\
2015\end{array}$ \\
\hline Domuz & $\begin{array}{l}30 \text { gün, diyet yağ oranın } \\
\% 3 \text { 'ü kadar MSG }\end{array}$ & $\begin{array}{l}\text { Faecalibacterium prausnitzii } \\
\text { popülasyonlarında artış }\end{array}$ & $\begin{array}{l}\text { Feng vd., } \\
2015\end{array}$ \\
\hline Fare & $\begin{array}{l}8 \mathrm{mg} / \mathrm{kg} / \text { gün } \\
\text { benzodyum } \\
\mathrm{mg} / \mathrm{kg} / \text { gün sodyum } \\
\text { nitrit ve } 19 \mathrm{mg} / \mathrm{kg} / \text { gün } \\
\text { potasyum sorbat }\end{array}$ & $\begin{array}{l}\text { Clostridiales sayılanında azalma ve Proteobacteria } \\
\text { sayılanında artış }\end{array}$ & $\begin{array}{l}\text { Hrncirava } \\
\text { vd., } \\
\text { 2019b }\end{array}$ \\
\hline Fare & $\begin{array}{l}3 \text { hafta, } 0,2,10 \text { ve } 50 \\
\mathrm{mg} / \text { gün } \mathrm{TiO}_{2}\end{array}$ & $\begin{array}{l}\text { Tüm dozlar Lactobacillus ve Allobaculum türleri; } 50 \\
\text { mg dozu } \mathrm{TiO}_{2} \text { Parabacteroides türlerinde artış; } 10 \\
\text { ve } 50 \mathrm{mg} \text { dozları Adlercrentzig ve } \\
\text { sinıflandırılmamıs Clostridiaceae türlerinde azalma }\end{array}$ & $\begin{array}{l}\text { Pinget } \\
\text { vd., } 2019\end{array}$ \\
\hline İnsan & 4 hafta, $2 \mathrm{~g} /$ gün MSG & $\begin{array}{l}\text { Mikrobiyota yapısı ve fonksiyonunu önemli } \\
\text { derecede etkilenmemiştir }\end{array}$ & $\begin{array}{l}\text { Peng vd., } \\
2018\end{array}$ \\
\hline
\end{tabular}

GKM: g1da katk1 maddesi, BA: benzoik asit, mg: miligram, ml: mililitre, g:gram, kg: kilogram, $\mathrm{TiO}_{2}$ : titanyum dioksit, MSG: monosodyum glutamat 


\section{SONUÇ}

Sonuç olarak, gida katkı maddelerinin mikrobiyota üzerine etkisini değerlendiren çalışmaların büyük çoğunluğunu hayvan çalışmaları oluşturmaktadır. Bilindiği üzere farklı hayvan modellerinde bağırsak mikrobiyota bileşimi ile bazı besinlerin metabolize olduğu bölgeler insanlardan farklilık gösterir. Yapılan çalışmalara göre, gida katkı maddelerinin büyük oranda disbiyozise yol açtı̆̆ görülürken, insanlarda etkileri hala belirsizliğini korumaktadır. İnsanlarda yapilacak randomize kontrollü çalışmalara ihtiyaç vardır fakat bireysel farklılıklar ve uzun süreli alışılmış beslenme alışkanlıkları da göz önüne alındığında bu çalışmaların oldukça titizlikle planlanmasi ve bu konunun aydınlatılması gerekmektedir.

\section{ÇIKAR ÇATIŞMASI BEYANI}

Yazarların, başka kişiler ve/veya kurumlar ile çıar çatışması bulunmamaktadır.

\section{YAZAR KATKILARI}

HMB ve SAÖ derlemeyi planlayarak, yazma, inceleme ve düzenleme aşamalarında katk1 sağlamışlardır. HMB ve SAÖ makalenin son halini okumuş ve onaylamıştır.

\section{KAYNAKLAR}

Abou-Donia, M.B., El-Masry, E.M., AbdelRahman, A.A., McLendon, R.E., Schiffman, S.S. (2008). Splenda alters gut microflora and increases intestinal p-glycoprotein and cytochrome p-450 in male rats. J Toxicol Environ Health Part A, 71(21): 1415-1429, doi:10.1080/15287390802328630.

Ahmad, S.Y., Friel, J.K., Mackay, D.S. (2020). Effect of sucralose and aspartame on glucose metabolism and gut hormones. Nutr Rev, 78(9): 725-746, doi:10.1093/nutrit/nuz099.

Ali, W.A.-G., Mohammed, S.A., Abdullah, E.M., ElDeen, E.M.S. (2019). Aspartame: basic information for toxicologists. Sohag Medical Joumal, 23(2): 47-51, doi:10.21608/SMJ. 2019.46212.

Amin, K. A., Al-Muzafar, H.M., Elsttar, A.H.A. (2016). Effect of sweetener and flavoring agent on oxidative indices, liver and kidney function levels in rats. Indian J Exp Biol, 54(1): 56-63.
Anderson, R., Kirkland, J.J. (1980). The effect of sodium saccharin in the diet on caecal microflora. Food Cosmet Toxicol, 18(4): 353-355, doi: 10.1016/0015-6264(80)90188-1.

Anderson, R.L. (1985). Some changes in gastrointestinal metabolism and in the urine and bladders of rats in response to sodium saccharin ingestion. Food Chem Toxicol, 23(4-5): 457-463, doi:10.1016/0278-6915(85)90140-1.

Ardalan, M.R., Tabibi, H., Attari, V.E., Mahdavi, A.M. (2017). Nephrotoxic effect of aspartame as an artificial sweetener: a brief review. Iran J Kidney Dis, 11(5): 339.

Bandyopadhyay, A., Ghoshal, S., Mukherjee, A. (2008). Genotoxicity testing of low-calorie sweeteners: aspartame, acesulfame-K, and saccharin. Drug Chem Toxicol, 31(4): 447-457, doi: 10.1080/01480540802390270.

Baranowska-Wójcik, E., Szwajgier, D., Oleszczuk, P., Winiarska-Mieczan, A. (2020). Effects of titanium dioxide nanoparticles exposure on human health-a review. Biol Trace Elem Res, 193: 118-129, doi: 10.1007/s12011-01901706-6.

Bellisle, F., Drewnowski, A. (2007). Intense sweeteners, energy intake and the control of body weight. Eur J Clin Nutr, 61(6): 691-700, doi: 10.1038/sj.ejcn.1602649.

Bian, X., Chi, L., Gao, B., Tu, P., Ru, H., Lu, K. (2017a). Gut microbiome response to sucralose and its potential role in inducing liver inflammation in mice. Front Physiol, 24(8): 487, doi: 10.3389 / fphys.2017.00487.

Bian, X., Chi, L., Gao, B., Tu, P., Ru, H., Lu, K. (2017b). The artificial sweetener acesulfame potassium affects the gut microbiome and body weight gain in CD-1 mice. PloS One, 12(6): e0178426, doi: 10.1371/journal.pone.0178426.

Bian, X., Tu, P., Chi, L., Gao, B., Ru, H., Lu, K. (2017c). Saccharin induced liver inflammation in mice by altering the gut microbiota and its metabolic functions. Food Chem Toxicol, 107: 530539, doi: 10.1016/j.fct.2017.04.045.

Biesiekierski, J. R., Jalanka, J., Staudacher, H. M. (2019). Can gut microbiota composition predict 
response to dietary treatments? Nutrients, 11(5): 1134, doi: $10.3390 /$ nu11051134.

Campbell, H.E., Escudier, M.P., Patel, P., Challacombe, S.J., Sanderson, J.D., Lomer, M.C. (2011). Cinnamon-and benzoate-free diet as a primary treatment for orofacial granulomatosis. Aliment Pharmacol Ther, 34(7): 687-701, doi:10.1111/j.1365-2036.2011.04792.x.

Cani, P. D., Everard, A. (2016). Talking microbes: when gut bacteria interact with diet and host organs. Mol Nutr Food Res, 60(1): 58-66, doi: 10.1002/mnfr.201500406.

Cao, Y., Liu, H., Qin, N., Ren, X., Zhu, B., Xia, $X$. (2020). Impact of food additives on the composition and function of gut microbiota: a review. Trends Food Sci Technol, 99: 295-310, doi: 10.1016/j.tifs.2020.03.006.

Chassaing, B., Koren, O., Goodrich, J.K., Poole, A.C., Srinivasan, S., Ley, R.E., Gewirtz, A.T. (2015). Dietary emulsifiers impact the mouse gut microbiota promoting colitis and metabolic syndrome. Nature, 519(7541): 92-96, doi: 10.1038/nature14232.

Chassaing, B., Van de Wiele, T., De Bodt, J., Marzorati, M., Gewirtz, A.T. (2017). Dietary emulsifiers directly alter human microbiota composition and gene expression ex vivo potentiating intestinal inflammation. Gut, 66(8): 1414-1427, doi:10.1136/gutjnl-2016-313099.

Chi, L., Bian, X., Gao, B., Tu, P., Lai, Y., Ru, H., Lu, K. (2018). Effects of the artificial sweetener neotame on the gut microbiome and fecal metabolites in mice. Molecules, 23(2): 367, doi: 10.3390/molecules23020367.

Choudhary, A.K., Pretorius, E. (2017). Revisiting the safety of aspartame. Nutr Rev, 75(9): 718-730, doi: $10.1093 /$ nutrit/nux035.

Clemente, J.C., Ursell, L.K., Parfrey, L.W., Knight, R. (2012). The impact of the gut microbiota on human health: an integrative view. Cell, $148(6)$ : 1258-1270, doi:10.1016/j.cell.2012.01.035.

Daly, K., Darby, A.C., Hall, N., Nau, A., Bravo, D., Shirazi-Beechey, S.P. (2014). Dietary supplementation with lactose or artificial sweetener enhances swine gut Lactobacillus population abundance. Br J Nutr, 111(S1): 30-35, doi: 10.1017/S0007114513002274.

Daly, K., Darby, A.C., Hall, N., Wilkinson, M.C., Pongchaikul, P., Bravo, D., Shirazi-Beechey, S.P. (2016). Bacterial sensing underlies artificial sweetener-induced growth of gut Lactobacillus. Environ Microbiol, 18(7): 2159-2171, doi: 10.1111/1462-2920.12942.

Del Olmo, A., Calzada, J., Nuñez, M. (2017). Benzoic acid and its derivatives as naturally occurring compounds in foods and as additives: uses, exposure, and controversy. Crit Rev Food Sci Nutr, 57(14): 3084-3103, doi:10.1080/10408398.2015.1087964.

Dhingra, R., Sullivan, L., Jacques, P.F., Wang, T.J., Fox, C.S., Meigs, J.B., D’Agostino, R.B., Gaziona, J.M., Vasan, R.S. (2007). Soft drink consumption and risk of developing cardiometabolic risk factors and the metabolic syndrome in middleaged adults in the community. Circulation, 116(5): 480-488, doi: 10.1161/CIRCULATIONAHA. 107.689935.

Diao, H., Zheng, P., Yu, B., He, J., Mao, X., Yu, J., Chen, D. (2015). Effects of benzoic acid and thymol on growth performance and gut characteristics of weaned piglets. Asian-Australas J Anim Sci, 28(6): 827-839, doi: 10.5713/ajas.14.0704.

Diao, H., Zheng, P., Yu, B., He, J., Mao, X., Yu, J., Chen, D. (2014). Effects of dietary supplementation with benzoic acid on intestinal morphological structure and microflora in weaned piglets. Livest Sci, 167: 249-256, doi: 10.1016/j.livsci.2014.05.029.

Eweka, A.O., Eweka, A., Om'iniabohs, F.A. (2010). Histological studies of the effects of monosodium glutamate of the fallopian tubes of adult female wistar rats. $N$ Am J Med Sci, 2(3): 146-149, doi: 10.4297/najms.2010.3146.

Falcon, T., Foletto, K.C., Siebert, M., Pinto, D.E., Andrades, M., Bertoluci, M.C. (2020). Metabarcoding reveals that a non-nutritive sweetener and sucrose yield similar gut microbiota patterns in wistar rats. Genet Mol Biol, 43(1): e20190028, doi: 10.1590/1678-4685-GMB-20190028 . 
Feng, Z.M., Li, T.J., Wu, L., Xiao, D.F., Blachier, F., Yin, Y.L. (2015). Monosodium L-glutamate and dietary fat differently modify the composition of the intestinal microbiota in growing pigs. Obesity facts, 8(2): 87-100, doi: 10.1159/000380889.

Findıklı, Z., Türkoğlu, Ş. (2014). Determination of the effects of some artificial sweeteners on human peripheral lymphocytes using the comet assay. J Toxicol Environ Health Sci, 6(8): 147-153, doi: 10.5897/JTEHS2014.0313.

Fitch, C., Keim, K.S. (2012). Position of the Academy of Nutrition and Dietetics: use of nutritive and nonnutritive sweeteners. J Acad Nutr Diet, 112(5): 739-758, doi: 10.1016/j.jand. 2012.03.009

Foletto, K.C., Melo Batista, B.A., Neves, A.M., de Matos Feijó, F., Ballard, C.R.,Marques Ribeiro, M.F.,Bertoluci, M.C. (2016). Sweet taste of saccharin induces weight gain without increasing caloric intake, not related to insulin-resistance in wistar rats. Appetite, 96: 604-610, doi: 10.1016/j.appet.2015.11.003.

Frankenfeld, C.L., Sikaroodi, M., Lamb, E., Shoemaker, S., Gillevet, P.M. (2015). Highintensity sweetener consumption and gut microbiome content and predicted gene function in a cross-sectional study of adults in the United States. Ann Epidemiol, 25(10): 736-742, doi: 10.1016/j.annepidem.2015.06.083.

Furuhashi, H., Higashiyama, M., Okada, Y., Kurihara, C., Wada, A., Horiuchi, K., Hanawa, Y., Mizoguchi, A., Nishii, S., Inaba, K., Sugihara, N., Watanabe, C., Komoto, S., Tomita, K., Miura, S., Hokari, R. (2020). Dietary emulsifier polysorbate80 -induced small-intestinal vulnerability to indomethacin-induced lesions via dysbiosis. J Gastroenterol Hepatol, 35(1): 110-117, doi: 10.1111/jgh.14808.

Gardana, C., Simonetti, P., Canzi, E., Zanchi, R., Pietta, P. (2003). Metabolism of stevioside and rebaudioside A from Stevia rebaudiana extracts by human microflora. J Agric Food Chem, 51(22): 6618-6622, doi: 10.1021/jf0303619.

Gong, T., Wei, Q.W., Mao, D.G., Nagaoka, K., Watanabe, G., Taya, K., Shi, F.X. (2016). Effects of daily exposure to saccharin and sucrose on testicular biologic functions in mice. Biol Reprod, 95(6): 116, doi: 10.1095/biolreprod.116.140889.

Grotz, V. L., Pi-Sunyer, X., Porte Jr, D., Roberts, A., Richard Trout, J. (2017). A 12-week randomized clinical trial investigating the potential for sucralose to affect glucose homeostasis. Regul Toxicol Pharmacol, 88: 22-33, doi: 10.1016/j.yrtph.2017.05.011.

Halas, D., Hansen, C.F., Hampson, D.J., Mullan, B.P., Kim, J.C., Wilson, R.H., Pluske, J.R. (2010). Dietary supplementation with benzoic acid improves apparent ileal digestibility of total nitrogen and increases villous height and caecal microbial diversity in weaner pigs. Anim Feed Sci Technol, 160(3-4): 137-147, doi: 10.1016/ j.anifeedsci.2010.07.001.

Halmos, E.P., Mack, A., Gibson, P.R. (2019). Emulsifiers in the food supply and implications for gastrointestinal disease. Aliment Pharmacol Ther, 49(1): 41-50, doi: 10.1111/apt.15045.

Hrncirova, L., Hudcovic, T., Sukova, E., Machova, V., Trckova, E., Krejse, J., Hrncir, T. (2019a). Human gut microbes are susceptible to antimicrobial food additives in vitro. Folia Microbiol, 64(4): 497-508, doi: 10.1007/ s12223-018-00674-z.

Hrncirova, L., Machova, V., Trckova, E., Krejse, J., Hrncir, T. (2019b). Food preservatives induce proteobacteria dysbiosis in human-microbiota associated Nod2-deficient mice. Microorganisms, 7(10): 383, doi: 10.3390/microorganisms 7100383 .

Husøy, T., Mangschou, B., Fotland, T.Ø., Kolset, S.O., Nøtvik Jakobsen, H., Tømmerberg, I., Bergsten, C., Alexander, J., Frost Andersen, L. (2008). Reducing added sugar intake in Norway by replacing sugar sweetened beverages with beverages containing intense sweeteners-a risk benefit assessment. Food Chem Toxicol, 46(9): 3099-3105, doi: 10.1016/j.fct.2008.06.013.

Hwang, J.S., Yu, J., Kim, H.M., Oh, J.M., Choi, S.J. (2019). Food additive titanium dioxide and its fate in commercial foods. J Nanomater, 9(8): 1175, doi: $10.3390 /$ nano9081175.

Iammarino, M., Di Taranto, A., Palermo, C., Muscarella, M. (2011). Survey of benzoic acid in 
cheeses: contribution to the estimation of an admissible maximum limit. Food Addit Contam B, 4(4): 231-237, doi: 10.1080/19393210.2011.620355.

Imamura, F., O’Connor, L., Ye, Z., Mursu, J., Hayashino, Y., Bhupathiraju, S.N., Forouhi, N. G. (2015). Consumption of sugar sweetened beverages, artificially sweetened beverages, and fruit juice and incidence of type 2 diabetes: systematic review, meta-analysis, and estimation of population attributable fraction. BMJ, 351: h3576, doi: 10.1136/bmj.h3576.

Irwin, S.V., Fisher, P., Graham, E., Malek, A., \& Robidoux, A. (2017). Sulfites inhibit the growth of four species of beneficial gut bacteria at concentrations regarded as safe for food. PloS One, 12(10): e0186629, doi: 10.1371/journal.pone. 0186629.

Isa, A. S., Muhammad, M.S., Hudu, A.A., Jamba, B.I., Choji, E.S., Isah, H.O., Magaji, M.G. (2019). Assessment of cognitive and motor endurance activities in male wistar rats administered carboxymethyl cellulose. Afr J Biomed Res, 22(2): 195-199.

John, C. (2016). Aspartame: an investigation of the use of artificial sweeteners. J Health Dispar Res Pract, 9(5): 61.

Józefiak, D., Kaczmarek, S., Bochenek, M., Rutkowski, A. (2007). A note on effects of benzoic acid supplementation on the performance and microbiota populations of broiler chickens. J Anim Feed Sci, 16(2): 252-256, doi:10.22358/jafs/66746/2007.

Kim, H.L., Ha, A.W., Kim, W.K. (2020). Effect of saccharin on inflammation in 3T3-L1 adipocytes and the related mechanism. Nutr Res Pract, 14(2): 109-116, doi: 10.4162/ nrp.2020.14.2.109.

Kluge, H., Broz, J., Eder, K. (2006). Effect of benzoic acid on growth performance, nutrient digestibility, nitrogen balance, gastrointestinal microflora and parameters of microbial metabolism in piglets. J Anim Physiol Anim Nutr, 90(7-8): 316-324, doi: 10.1111/j.14390396.2005.00604.x.
Lawrie, C., Renwick, A.G., Sims, J. (1985). The urinary excretion of bacterial amino-acid metabolites by rats fed saccharin in the diet. Food Chem Toxicol, 23(4-5): 445-450, doi: 10.1016/0278-6915(85)90138-3.

Le Roy, C.I., Bowyer, R.C.E., Castillo-Fernandez, J.E., Pallister, T., Menni, C., Steves, C.J., Berry, S.E., Spector, T.D., Bell, J.T. (2019). Dissecting the role of the gut microbiota and diet on visceral fat mass accumulation. Sci Rep, 9(1): 9758, doi: 10.1038/s41598-019-46193-w.

Lindemann, B., Ogiwara, Y., Ninomiya, Y. (2002). The discovery of umami. Chem Senses, 27(9): 843-844, doi: 10.1093/chemse/27.9.843.

Mallett, A.K., Rowland, I.R., Bearne, C.A. (1985). Modification of rat caecal microbial biotransformation activities by dietary saccharin. Toxicology, 36(2-3): 253-262, doi: 10.1016/0300483x(85)90058-7.

Matysková, R., Maletínská, L., Maixnerová, J., Pirník, Z., Kiss, A., Zelezná, B. (2008). Comparison of the obesity phenotypes related to monosodium glutamate effect on arcuate nucleus and/or the high fat diet feeding in C57BL/ 6 and NMRI mice. Physiol Res, 57: 727-734.

Mayhew, D.A., Comer, C.P., Stargel, W.W. (2003). Food consumption and body weight changes with neotame, a new sweetener with intense taste: differentiating effects of palatability from toxicity in dietary safety studies. Regul Toxicol Pharmacol, 38(2): 124-143, doi: 10.1016/s02732300(03)00074-6.

Naim, M., Zechman, J.M., Brand, J.G., Kare, M.R., Sandovsky, V. (1985). Effects of sodium saccharin on the activity of trypsin, chymotrypsin, and amylase and upon bacteria in small intestinal contents of rats. Proc Soc Exp Biol Med, 178(3): 392-401, doi: 10.3181/00379727-178-42022.

Niaz, K., Zaplatic, E., \& Spoor, J. (2018). Extensive use of monosodium glutamate: a threat to public health? EXCLI J, 17: 273-278, doi: 10.17179/excli2018-1092.

Ortiz, G.G., Bitzer-Quintero, O.K., Zárate, C.B., Rodríguez-Reynoso, S., Larios-Arceo, F., Velázquez-Brizuela, I.E., Pacheco-Moisés, F., Rosales-Corral, S.A. (2006). Monosodium 
glutamate-induced damage in liver and kidney: a morphological and biochemical approach. Biomed Pharmacother, 60(2): 86-91, doi: 10.1016/j.biopha.2005.07.012.

Özbek, Y., Yentür, G. (1993). Gidalarda aspartamin katk1 maddesi olarak kullanılması. GID $A, 18(1):$ 67-71.

Özdemir, D., Başer, H., Çakıı, B. (2014). Tatlandırcclar. Türkiye Klinikleri Endokrinoloji Dergisi, 9(2): 60-70.

Öztürkcan, S.A., Acar, S. (2017). Yayg1n olarak kullanılan antimikrobiyal gida katk1 maddeleri ile ilgili genel bir değerlendirme. IGÜS ABDER, 1(1): 1-17.

Palmnäs, M.S., Cowan, T.E., Bomhof, M.R., Su, J., Reimer, R.A., Vogel, H.J., Hittel, D.S., Shearer, J. (2014). Low-dose aspartame consumption differentially affects gut microbiota-host metabolic interactions in the diet-induced obese rat. PloS One, 9(10): e109841, doi: 10.1371/journal.pone.0109841

Peng, Q., Huo, D., Ma, C., Jiang, S., Wang, L., Zhang, J. (2018). Monosodium glutamate induces limited modulation in gut microbiota. J Funct Foods, 49: 493-500, doi: $10.1016 /$ j.jff.2018.09.015.

Pepino, M.Y., Tiemann, C D., Patterson, B.W., Wice, B.M., \& Klein, S. (2013). Sucralose affects glycemic and hormonal responses to an oral glucose load. Diabetes Care, 36(9): 2530-2535, doi: $10.2337 /$ dc12-2221.

Pepino, M.Y. (2018). The not-so-sweet effects of sucralose on blood sugar control. Am J Clin Nutr, 108(3): 431-432, doi: 10.1093/ajcn/nqy205.

Pinget, G., Tan, J., Janac,B., Kaakoush, N.O., Angelatos, A.S., O'Sullivan, J., Koay, Y.C., Sierro, F., Davis, J., Divakarla, S.K., Khanal, D., Moore, R.J., Stanley, D., Chrzanowski, W., Macia, L. (2019). Impact of the food additive titanium dioxide (E171) on gut microbiota-host interaction. Front Nutr, 2019(6): 57, doi: 10.3389/fnut.2019.00057.

Roca-Saavedra, P., Mendez-Vilabrille, V., Miranda, J M., Nebot, C., Cardelle-Cobas, A., Franco, C.M., Cepeda, A. (2018). Food additives, contaminants and other minor components: effects on human gut microbiota-a review. $J$ Physiol Biochem, 74(1): 69-83, doi: 10.1007/s13105017-0564-2

Rodriguez-Palacios, A., Harding, A., Menghini, P., Himmelman, C., Retuerto, M., Nickerson, K.P., Lam, M., Croniger, C.M., McLean, M.H., Durum, S.K., Pizarro, T.T., Ghannoum, M.A., Ilic, S., McDonald, C., Cominelli, F. (2018). The artificial sweetener splenda promotes gut proteobacteria, dysbiosis, and myeloperoxidase reactivity in Crohn's disease-like ileitis. Inflamm Bowel Dis, 24(5): 1005-1020, doi: 10.1093/ibd/izy060.

Ruiz-Ojeda, F.J., Plaza-Díaz, J., Sáez-Lara, M.J., Gil, A. (2019). Effects of sweeteners on the gut microbiota: a review of experimental studies and clinical trials. Adv Nutr, 10(suppl_1): S31-S48, doi: 10.1093/advances/nmy037.

Saad, R., Rizkallah, M.R., Aziz, R K. (2012). Gut Pharmacomicrobiomics: the tip of an iceberg of complex interactions between drugs and gutassociated microbes. Gut Pathog, 4(1): 16, doi: 10.1186/1757-4749-4-16.

Salminen, S., Salminen, E., Bridges, J., Marks, V. (1986). The effects of sorbitol on the gastrointestinal microflora in rats. $Z$ Ernabrungswiss, 25(2): 91-95.

Santos, N.C., de Araujo, L.M., De Luca Canto, G., Guerra, E.N.S., Coelho, M.S., Borin, M.F. (2018). Metabolic effects of aspartame in adulthood: a systematic review and meta-analysis of randomized clinical trials. Crit Rev Food Sci Nutr, 58(12): 2068-2081, doi: 10.1080/10408398.2017.1304358.

Sanyaolu, A., Marinkovic, A., Gosse, J., Likaj, L., Ayodele, O., Okorie, C., Verner, O. (2019). Artificial sweeteners and their association with diabetes: a review. Public Health Nutr, 1(4): 1-3.

Schoeler, M., Caesar, R. (2019). Dietary lipids, gut microbiota and lipid metabolism. Rev Endocr Metab Dis, 20(4): 461-472, doi: 10.1007/s11154-01909512-0. 
Sekirov, I., Russell, S.L., Antunes, L.C., Finlay, B.B. (2010). Gut microbiota in health and disease. Am J Physiol Cell Physiol, 90(3): 859-904, doi: 10.1152/physrev.00045.2009.

Serrano, E., Riebl, S. (2019). Non nutritive are they safe? Virginia Cooperative Extension, Virginia State University, Virginia, Amerika Birleşik Devletleri, 1 -5.

Singh, R.K., Wheildon, N., Ishikawa, S. (2016). Food additive P-80 impacts mouse gut microbiota promoting intestinal inflammation, obesity and liver dysfunction. SOJ Microbiol Infect Dis, 4(1): 110, doi: 10.15226/sojmid/4/1/00148.

Suez, J., Korem, T., Zeevi, D., ZilbermanSchapira, G., Thaiss, C.A., Maza, O., Israeli, D., Zmora, N., Gilad, S., Weinberger, A., Kuperman, Y., Harmelin, A., Kolodkin-Gal, I., Shapiro, H., Halpern, Z., Segal, E., Elinav, E. (2014). Artificial sweeteners induce glucose intolerance by altering the gut microbiota. Nature, 514(7521): 181-186, doi: 10.1038/nature13793.

Suez, J., Korem, T., Zilberman-Schapira, G., Segal, E., Elinav, E. (2015). Non-caloric artificial sweeteners and the microbiome: findings and challenges. Gut Microbes, 6(2): 149-155, doi: 10.1080/19490976.2015.1017700.

Swidsinski, A., Ung, V., Sydora, B.C., LoeningBaucke, V., Doerffel, Y., Verstraelen, H., Fedorak, R. N. (2009). Bacterial overgrowth and inflammation of small intestine after carboxymethylcellulose ingestion in genetically susceptible mice. Inflamm Bowel Dis, 15(3): 359364, doi: 10.1002/ibd.20763.

Temizkan, S., Deyneli, O., Yasar, M., Arpa, M., Gunes, M., Yazici, D., Sirikci, O., Haklar, G., Imeryuz, N., Yavuz, D.G. (2015). Sucralose enhances GLP-1 release and lowers blood glucose in the presence of carbohydrate in healthy subjects but not in patients with type 2 diabetes. Eur JClin Nutr, 69(2): 162-166, doi: 10.1038/ejcn.2014.208.

Thomson, P., Santibañez, R., Aguirre, C.,Galgani, J.E., Garrido, D. (2019). Short-term impact of sucralose consumption on the metabolic response and gut microbiome of healthy adults. $\mathrm{Br} J \mathrm{Nutr}$, 122(8): $\quad 856-862, \quad$ doi: $10.1017 / \mathrm{S} 0007114519001570$.

Uebanso, T., Ohnishi, A., Kitayama, R., Yoshimoto, A., Nakahashi, M., Shimohata, T., Mawata, K., Takahashi, A. (2017). Effects of lowdose non-caloric sweetener consumption on gut microbiota in mice. Nutrients, 9(6): 560, doi: 10.3390/nu9060560.

Vamanu, E., Pelinescu, D., Florentina Gatea, F., Sârbu, I. (2019). Altered in vitro metabolomic response of the human microbiota to sweeteners. Genes, 10(7): 535, doi: 10.3390/genes10070535.

Viennois, E., Merlin, D., Gewirtz, A.T., Chassaing, B. (2017). Dietary emulsifier-induced low-grade inflammation promotes colon carcinogenesis. Cancer Res, 77(1): 27-40, doi: 10.1158/0008-5472.CAN-16-1359.

Viennois, E., Chassaing, B. (2018). First victim, later aggressor: How the intestinal microbiota drives the pro-inflammatory effects of dietary emulsifiers? Gut microbes, 9(3): 1-4, doi: 10.1080/19490976.2017.1421885.

Wang, B., Yao, M., Lv, L., Ling, Z., Li, L. (2017). The human microbiota in health and disease. $J$ Eng, 3(1): 71-82, doi: 10.1016/ J.ENG.2017.01.008

Wang, Q.P., Browman, D., Herzog, H., Neely, G.G. (2018). Non-nutritive sweeteners possess a bacteriostatic effect and alter gut microbiota in mice. PloS One, 13(7): e0199080, doi: 10.1371/journal.pone.0199080.

Zhao, X., Yan, J., Chen, K., Song, L., Sun, B., Wei, X. (2018). Effects of saccharin supplementation on body weight, sweet receptor mRNA expression and appetite signals regulation in postweanling rats. Peptides, 107: 32-38, doi: 10.1016/j.peptides.2018.07.006.

Zmora, N., Suez, J., Elinav, E. (2019). You are what you eat: diet, health and the gut microbiota. Nat Rev Gastro Hepat, 16(1): 35-56, doi: 10.1038/s41575-018-0061-2. 